\title{
1 Hybridization of food governance: An analytical framework
}

\section{Paul Verbruggen and Tetty Havinga}

\section{INTRODUCTION}

The governance of food has changed dramatically since the 1990s. The outbreak of recurrent major food safety crises (including BSE), the globalization of food supply chains, the growing concentration of economic power among food retailers, a general perception of failing public regulation, and new concerns among consumers about animal welfare, dietary habits, the environment and fair trade have been identified in the literature as important drivers of changes in the institutions and practices of food governance. ${ }^{1}$ These changes have occurred across two dimensions: (i) national systems of food governance have been increasingly subject to international influences; and (ii) public food governance has been challenged, complemented or at times superseded by private governance systems.

As regards the first dimension, it should be noted that national food safety laws and enforcement mechanisms have been amended in the light of demands set by international government organizations or global trade. In the context of the European Union, for example, the Member States have been required to revise national legislation and establish new regulatory agencies or reform existing ones to oversee food businesses after the adoption of new EU legislation on food safety. ${ }^{2}$ In addition, the European

1 Tetty Havinga, Donal Casey and Frans Van Waarden, 'Changing Regulatory Arrangements in Food Governance' in Tetty Havinga, Frans Van Waarden, Donal Casey (eds), The Changing Landscape of Food Governance (Edward Elgar 2015); Paul Verbruggen and Tetty Havinga, 'Patterns of Interplay between Public and Private Food Regulators: An Introduction' (2015) 6 European Journal of Risk Regulation - special issue on Patterns of Interplay between Public and Private Regulation in Food Governance 482.

2 Ellen Vos and Frank Wendler (eds), Food Safety Regulation in Europe. A Comparative Institutional Analysis (Intersentia 2006); Gabriele Abels and Alexander 
Union established the European Food Safety Authority and the Food and Veterinary Office, ${ }^{3}$ in part to improve government responses to food crises and enhance coordination between national food safety authorities to better control risks in transnational food chains. ${ }^{4}$ At the global level, standards, codes of practice and guidelines set by the Codex Alimentarius Commission (Codex) play an important role in shaping national laws and government policies on food safety. ${ }^{5}$ National systems of food governance may also be exposed to pressures from importing countries to amend and ratchet up local standards. A prominent example here is China, which after experiencing strict food safety demands from importing countries, has sought to improve its national laws and enforcement mechanisms in order to gain access to international markets. ${ }^{6}$

The second dimension of the transition in food governance concerns the increased importance of standards, procedures and networks developed and governed by private, non-state actors to enhance and coordinate matters of food safety and sustainability. Retailers have been at the forefront of this development and have devised elaborate food standards and accompanying certification schemes with the purpose of controlling and managing food safety risks along their transnational supply chains. ${ }^{7}$ The uptake of these standards in the market has been significant ${ }^{8}$ and

Kobusch, 'Regulation of Food Safety in the EU: Explaining Organizational Diversity among Member States' in Havinga, Van Waarden, Casey (n 1) 39.

3 In 2016 this office was renamed the Health and Food Audits and Analysis Directorate of the European Commission's Directorate General Health and Food Safety (DG SANTE).

4 Alberto Alemanno, 'Food Safety and the Single European Market' in Christopher Ansell and David Vogel (eds), What's the Beef? The Contested Governance of European Food Safety (MIT Press 2006), 237.

5 Jessica Vapnek and Melvin Spreij, 'Perspectives and Guidelines on Food Legislation, with a New Model of Food Law' (FAO Legislative Study no. 87) 2005, accessed 24 November 2016 at http://www.fao.org/3/a-a0274e.pdf, 38 and Caoimhín MacMaoláin, Food Law. European, Domestic and International Frameworks (Hart Publishing 2015), 45.

6 Fred Gale and Jean C. Buzby, Imports from China and Food Safety Issues (United States Department of Agriculture Report), accessed 24 November 2016 at https://papers.ssrn.com/sol3/papers.cfm?abstract_id=1739127 and Kai Kottenstede, Chapter 10 in this volume. See for experiences of African countries the contribution of Kévine Kindji and Michael Faure, Chapter 12 in this volume.

7 Tetty Havinga, 'Retail Driven Food Safety Regulation' in Abdelhakim Hammoudi, Christina Grazia, Yves Surry and Jean-Baptiste Traversac (eds), Food Safety, Market Organization, Trade and Development (Springer 2015) 59, 72.

8 As early as 2006, a survey of the world's leading supermarkets found that an estimated $75-99 \%$ of food supplies sold by supermarket chains were certified against their private food safety standards. See Linda Fulponi, 'Private Voluntary 
the standards are reported to have an impact on market access, production processes and public standard setting activities. ${ }^{9}$ Civil society actors (NGOs, consumers, religious organizations and other public interest groups) have also developed private standards and certification schemes that have come to play an important role in specific domains of food governance, such as fair trade, sustainability and religious qualifications. ${ }^{10} \mathrm{On}$ other occasions, business and civil society have teamed up to devise joint ventures (such as the Marine Stewardship Council) or meta-regulatory organizations (such as the Global Food Safety Initiative - GFSI and the ISEAL Alliance) to improve and coordinate their methods of setting standards and certification of food businesses. ${ }^{11}$

Both transitions challenge - yet do not dismiss - the capacity of nation states to devise effective systems of food governance. Today's food governance is no longer an attribute of national governments alone, but is increasingly hybrid, that is, the result of coordinated public and private regulatory activities that frequently transcend national state boundaries. ${ }^{12}$ It is this hybridization of food governance, its trends, types and results that this book discusses. In analysing this practice and its consequences, as we explain in further detail below, the contributions in this book adopt an actor-centred perspective as the key to understanding that contemporary food governance lies in the interplay between different public and private

Standards in the Food System: The Perspective of Major Food Retailers in OECD Countries' (2006) 31 Food Policy 1.

9 Spencer Henson and John Humphrey, The Impacts of Private Food Safety Standards on the Food Chain and on Public Standard-Setting Processes, Paper Prepared for FAO/WHO May 2009, accessed 24 November 2016 at http://www. fao.org/docrep/012/i1132e/i1132e00.pdf.

10 Frans Van Waarden and Robin Van Dalen, 'Halal and the Moral Construction of Quality: How Religious Norms Turn a Mass Product into a Singularity' in Jens Beckert and Christine Musselin (eds), Constructing Quality: The Classification of Goods in Markets (Oxford University Press 2013) 197; Timothy D Lytton, Kosher: Private Regulation in the Age of Industrial Food (Harvard University Press 2013).

11 Allison Loconto and Eve Foullieux, 'Politics of Private Regulation: ISEAL and the Shaping of Transnational Sustainability Governance' (2013) 8 Regulation \& Governance 166; Paul Verbruggen and Tetty Havinga, 'The Rise of Transnational Private Meta-Regulators' (2016) 21 Tilburg Law Review 116.

12 Along the same lines Marsden et al. have suggested that food governance in Europe and beyond has moved towards a 'hybrid model' that reflects a new balance between public and private actors in the regulation and governance of food. Terry Marsden, Robert Lee, Andrew Flynn and Samarthia Thankappan, The New Regulation and Governance of Food. Beyond the Food Crisis? (Routledge 2010). See for a US perspective: Alexia Brunet Marks, 'A New Governance Recipe for Food Safety Regulation’ (2016) 47 Loyola University Chicago Law Journal 907. 
actors, including their relative interests and capacities, and their activities at different levels of governance.

\section{CONCEPTUALIZING HYBRIDIZATION}

What is meant by 'hybridization'? Scholars have observed a trend towards hybridization in regulation and governance. Levi-Faur developed the notion of regulatory capitalism to map and explain the mushrooming of regulation in the last decades in response to the rhetoric of many governments that we are supposed to live in an 'era of deregulation'. ${ }^{13}$ More specifically, regulatory capitalism denotes the changes and growth in instruments, scope, sectors and depth of regulation and is suggestive of a concept of regulation that is increasingly hybrid in nature. ${ }^{14}$ This hybridization not only covers the 'who' (public v. private actors) of today's regulation, but also the 'how' (command-and-control v. responsive regulation, coercive v. voluntary), the 'where' (global, local or intermediate level), and the 'what' (business v. social regulation). Levi-Faur therefore submits that: 'the study of regulatory governance should proceed beyond states, markets and societies into the identification of hybrid forms of regulation and towards the creation of autonomous regulatory spaces that blur the distinctions between the global and the national'. ${ }^{15}$ Elsewhere he writes:

[T] he major question [. . .] is to determine not which pure mode of governance is more effective or more legitimate but which hybrids are. We need to conceptualize a world order where governance is increasingly a hybrid of different systems of regulatory control $(. .)^{16}$

The new landscape of food governance offers a playground, as it were, to start exploring these issues.

In the existing literature on (regulatory) governance, the concept of

13 David Levi-Faur 'The Global Diffusion of Regulatory Capitalism' (2005) 598 The Annals of the American Academy of Political and Social Sciences 12.

14 John Braithwaite, Regulatory Capitalism: How it Works, Ideas for Making it Work Better (Edward Elgar 2008) and David Levi-Faur, 'Regulation and Regulatory Governance', (2010) Jerusalem Papers in Regulation \& Governance Working (No 1), accessed 24 November 2016 at http://regulation.huji.ac.il/papers/ jp1.pdf, 9-10.

15 Levi-Faur (n 14), 3.

16 David Levi-Faur, "From "Big Government" to "Big Governance" in David Levi-Faur (ed), Oxford Handbook on Governance (Oxford University Press 2012) 3,14 . 
'hybridization' or 'hybrid forms of governance' is not clearly demarcated. At least two different components are involved in a hybrid, and together they form a mixture, crossover or intermediate form of governance. Authors differ as regards the components they refer to. For some a hybrid form of governance involves both public (state) and private (non-state) actors. ${ }^{17}$ Others include different combinations of actors in the concept of hybridization. Levi-Faur, for example, distinguishes four hybrid forms of regulation, three involving a combination of different regulators and regulatees, the fourth being multilevel regulation. ${ }^{18}$ Thus, for Levi-Faur, a hybrid form can consist of only state or only non-state actors as long as they perform different roles or operate on a different level.

Yet others link hybridity to the combination of different regulatory approaches or instruments. For Bartle, for example, a 'hybrid approach' is a combination of command-and-control, market-based, and voluntary approaches involving 'a variety of actors and institutions pursuing different strategies and interacting in complex ways' ${ }^{19}$ Here, hybridity is primarily the combination of various approaches or mechanisms employed by different actors. Halpern introduces yet another perspective, namely that of multi-stakeholder governance. For him, hybridity in regulatory governance not only emerges from regulation that combines public and private components or oversight arrangements with multiple levels (joining centralized and regional or local features), but also from regulatory processes that engage the full range of participants concerned with regulatory regimes, including professionals, divisions of government, public interest advocates, and representatives of groups being regulated. ${ }^{20}$

17 Julia Black 'Decentring Regulation: Understanding the Role of Regulation and Self Regulation in a "Post-regulatory" World' (2001) 54 Current Legal Problems 103; Jeroen Van der Heijden, 'Friends, Enemies or Strangers? On Relationships between Public and Private Sector Service Providers in Hybrid Forms of Governance' (2011) 33 Law \& Policy 367 and Peer Zumbansen, 'Neither "Public" nor "Private", "National" nor "International": Transnational Corporate Governance from a Legal Pluralist Perspective' (2011) 38 Journal of Law and Society 50.

18 David Levi-Faur, 'Regulation and Regulatory Governance' in David LeviFaur (ed.) Handbook on the Politics of Regulation (Edward Elgar 2011) 3, 10-11.

19 Ian Bartle 'Regulatory Approaches to Climate Change Mitigation' in LeviFaur (n 18) 635.

20 Sydney Halpern, 'Hybrid Design, Systemic Rigidity: Institutional Dynamics in Human Subjects Oversight' (2008) 2 Regulation \& Governance 85, 85. 


\section{AN ACTOR-CENTRED PERSPECTIVE}

Common to these conceptualizations of hybridization in regulation and governance is the involvement of different types of actors in governance arrangements. In discussing the hybridization of contemporary food governance, the contributions in this book focus on arrangements that combine public and private (both business and civil society) actors, and analyse and discuss the interplay between these actors in such arrangements.

Examining the ongoing hybridization of food governance from this actor-centred perspective is particularly interesting for a number of reasons. First of all, food governance arrangements involving both public and private actors are relatively new and have not often been studied. ${ }^{21}$ Most food safety rules are developed either by the state or industry, whereas initiatives concerning interests such as fair trade, environment or animal welfare stem largely from civil society. Hybrid arrangements have emerged to overcome problems associated with state, industry or NGO-driven governance, but research on the attributes and added value of hybrids is still scarce.

Furthermore, the mixing and matching of public and private initiatives in hybrid governance arrangements is certain to give rise to specific challenges. Government and business organizations operate through different rationalities (public interest v. market gains). These opposing logics are likely to lead to conflict at the level of the protection offered, the way in which monitoring should be organized or the sanctions that should follow, should the regulated food business fail to comply. This raises the question of how such conflicts might be managed and resolved. At a more fundamental level, the question arises of how responsibilities and risks are allocated between the different actors constituting the hybrid arrangement. Who gets to decide, and how are the interests of those concerned represented in decision-making? To what extent do these practices meet conventions of (democratic) legitimacy and accountability? These questions are explored in the contributions in the first part of this volume.

To be sure, an actor-centred perspective regarding the theme of hybridization of food governance does not discard the important questions concerning governance strategies and the appropriate level of today's food

21 A notable exception is the self-regulatory mechanism developed by the Dutch dairy industry in the late 1800 s to reduce adulteration of and fraud with dairy products, which received government support as of 1904. See Frans van Waarden, 'Varieties of Collective Self-Regulation of Business: the Example of the Dutch Dairy Industry' in Wolfgang Streeck and Philip Schmitter (eds), Private Interest Government. Beyond Market and State (Sage 1985). 
governance. The question of 'who' governs is intimately connected with the question of 'how' one governs, that is, by which strategies the actors concerned seek to influence food production (command-and-control v. responsive regulation, coercive v. voluntary) and at which level of governance the actors choose to operate (global, local or intermediate levels).

\section{ORGANIZING HYBRIDIZATION OF FOOD GOVERNANCE}

Abbott and Snidal organize the variety of actors involved in transnational regulatory standard setting in their influential 'Governance Triangle'. Their illustration is based on the direct involvement of three groups of actors in standard setting processes, namely states, firms and NGOs. The separate zones in the triangle suggest three forms of single-actor standards (zones 1-3), three forms of dual-actor standards (zones 4-6), and one form of standard involving direct participation of all three groups of actors (zone 7). As noted, most food safety standards can be situated in zone 1 (state regulation) and zone 2 (industry self-regulation), whereas food standards regarding fair trade, environment or animal welfare largely appear in zone 3 (civil society). Figure 1.1 depicts the Governance Triangle for standard setting in the domain of (transnational) food governance and locates in its different zones examples discussed in the contributions to this volume (see Table 1.1).

Organizing food standard setting along the lines of Abbott and Snidal's Governance Triangle appears to suggest that hybridization in this field emerges mostly in zones 4 and 6 . An example of food standards that are set in collaboration between states and firms concerns guides to good hygienic practice. These guides offer food businesses in Europe practical guidance on how to comply with the obligation under EU hygiene law to have in place an HACCP-based risk management system (see in detail Bernd van der Meulen, Chapter 6 in this volume). While these guides are drafted by the food industry representatives or specific food sectors, competent authorities of the EU Member States must approve these codes and forward them to the European Commission to register them in a database. Similarly, pan-EU codes might be developed by European industry associations, which then require the approval of the European Commission.

An example of hybrid standard setting that can be situated in zone 5 is ISEAL. This non-profit, membership organization develops codes of good practice for standard-setting organizations. The codes developed by ISEAL offer best practice guidelines for standard setting, compliance verification, and impact assessment. To develop these codes, ISEAL draws on (inter alia) experience by its member organizations, which include standard 


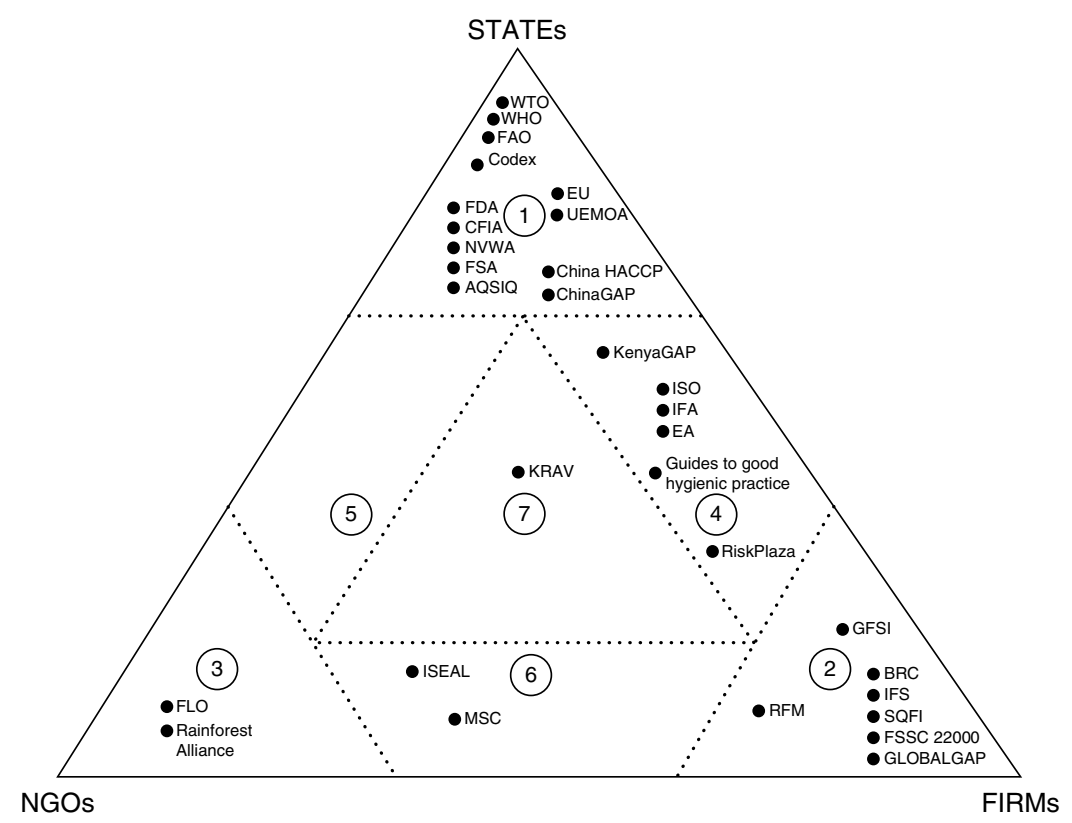

Source: Adapted from: Kenneth W. Abbott and Duncan Snidal 'The Governance Triangle: Regulatory Standards Institutions in the Shadow of the State' in Walter Mattli and Ngaire Woods (eds), The Politics of Global Regulation (Princeton University Press 2009) 50.

Figure 1.1 The Governance Triangle of food standard setters

setters from both civil society (for example, Fairtrade International and Rainforest Alliance) and industry (for example, UTZ). ISEAL Members may themselves also constitute hybrid standard setters. For example, the Marine Stewardship Council (MSC), which was established jointly by the World Wide Fund for Nature (WWF) and Unilever, adopts private standards for sustainable wild-captured fish. Another example is the Roundtable on Sustainable Palm Oil (RSPO), which includes members drawn from both industry and civil society to set standards for the sustainable production of palm oil products (including food).

Finally, the governance of organic food in Sweden through the KRAV label can be presented as an example of hybridization of standard setting in zone 7. The label seeks to ensure compliance with the government (European Union) requirements for organically produced food and is as such officially recognized by the Swedish government. ${ }^{22} \mathrm{KRAV}$, which

22 Magnus Boström and Mikael Klintman, 'State-Centered versus Nonstate- 
Table 1.1 Standard setters in (hybrid) food governance

\begin{tabular}{|c|c|c|}
\hline Zone & Organization/standard & Discussed in \\
\hline \multirow[t]{13}{*}{ Zone 1} & WTO - World Trade Organization & Chapters 2, 9 \\
\hline & WHO - World Health Organization & Chapter 9 \\
\hline & FAO - Food and Agriculture Organization & Chapters 9,11 \\
\hline & Codex - Codex Alimentarius Commission & Chapters 1,9 \\
\hline & EU - European Union & Chapters $6,7,8$ \\
\hline & $\begin{array}{l}\text { UEMOA - Union économique et monétaire } \\
\text { ouest-africaine }\end{array}$ & Chapter 12 \\
\hline & FDA - US Food and Drug Administration & Chapters 4,9 \\
\hline & CFIA - Canadian Food Inspection Agency & Chapter 9 \\
\hline & NVWA - Nederlandse Voedsel- en Warenautoriteit & Chapter 9 \\
\hline & FSA - UK Food Standards Agency & Chapter 7 \\
\hline & $\begin{array}{l}\text { AQSIQ - Chinese Administration of Quality } \\
\text { Supervision, Inspection and Quarantine }\end{array}$ & Chapter 10 \\
\hline & China HACCP & Chapters 9,10 \\
\hline & ChinaGAP & Chapters 10 \\
\hline \multirow[t]{7}{*}{ Zone 2} & GFSI - Global Food Safety Initiative & Chapters $3,4,9,10$ \\
\hline & BRC - British Retail Consortium & Chapters 9,10 \\
\hline & IFS - International Featured Standards & Chapter 10 \\
\hline & SQF - Safe Quality Food & Chapter 4 \\
\hline & FSSC 22000 - Food Safety System Certification & Chapters 9,10 \\
\hline & $\begin{array}{l}\text { GLOBALGAP - Global Partnership for Good } \\
\text { Agricultural Practices }\end{array}$ & Chapters $2,9,10$ \\
\hline & RFM - Responsible Fisheries Management & Chapter 11 \\
\hline \multirow[t]{2}{*}{ Zone 3} & FLO - Fairtrade International & Chapter 1 \\
\hline & Rainforest Alliance & Chapter 1 \\
\hline \multirow[t]{6}{*}{ Zone 4} & KenyaGAP & Chapters 1,12 \\
\hline & ISO - International Standardization Organization & Chapter 2 \\
\hline & IAF - International Accreditation Forum & Chapter 2 \\
\hline & EA - European Co-operation for Accreditation & Chapter 2 \\
\hline & Guides to good hygienic practice & Chapter 6 \\
\hline & RiskPlaza & Chapter 9 \\
\hline \multicolumn{3}{|l|}{ Zone 5} \\
\hline \multirow[t]{2}{*}{ Zone 6} & ISEAL - The ISEAL Alliance & Chapters 1,2 \\
\hline & MSC - Marine Stewardship Council & Chapter 11 \\
\hline Zone 7 & KRAV - Kontrollföreningen för alternativ odling & Chapters 1,11 \\
\hline
\end{tabular}

sets the standards underpinning the certificate, is a private association with a membership that represents farmers, processors and trade, as well as consumer, environmental and animal welfare interests.

Driven Organic Food Standardization: A Comparison of the US and Sweden' (2006) 23 Agriculture and Human Values 163. 
The Governance Triangle illustrated in Figure 1.1 draws a very rough picture of the hybridization of food governance. First of all, the threefold categorization of actors involved in standard setting (states, firms and NGOs) appears insufficient to analyse the dynamics of private or hybrid systems of food governance since it fails to capture the interdependence between these actors, as well as the conflicts of interest and power struggles between them..$^{23}$ To do so, we need a more sophisticated classification, distinguishing between private actors that are being regulated (regulatees), private actors that are part of the production chain but are not themselves regulated by the regulation under consideration but benefit from its application (beneficiaries, such as suppliers, retailers and consumers), ${ }^{24}$ and private actors providing compliance and intermediary services to the regulated industry (intermediaries, such as accreditation, certification and consultancy bodies). ${ }^{25}$

Consider the example of GlobalGAP (see in detail Donal Casey, Chapter 2 in this volume). GlobalGAP is a private, not-for-profit organization setting voluntary private standards for the certification of agricultural products. Its standards are classified as a single-actor standard in the Governance Triangle (zone 2). In reality, however, GlobalGAP's membership is far from homogeneous and represents a wide range of industry actors, all with very different positions and interests. GlobalGAP was originally set up by European supermarket chains to adopt standards for the certification of agricultural products around the globe, but now also involves non-European retailers. Moreover, GlobalGAP's membership is no longer limited to retailers but includes retailers and food service firms, producers and suppliers, and associate members such as certification bodies, consultancy firms and the pest control industry (crop protection). Conflicts of interest exist among these membership categories, that is, between retailers and suppliers, between developed and developing countries, between small farmers and large food wholesalers. But conflicts also arise within membership categories, as the struggles between

23 Cf Tetty Havinga, 'Conceptualizing Regulatory Arrangements: Complex Networks of Actors and Regulatory Roles' in Havinga, Van Waarden, Casey (n 1) 24-5.

24 Fabrizio Cafaggi, 'New Foundations of Transnational Private Regulation' (2011) 38 Journal of Legal Studies 20, 31-8.

25 Kenneth W. Abbott, David Levi-Faur and Duncan Snidal, 'Regulatory Intermediaries in the Age of Governance' (2017) 670 Annals of the American Academy for Political and Social Sciences - Special Issue (forthcoming) and Tetty Havinga and Paul Verbruggen, 'Understanding Complex Governance Relationships in Food Safety Regulation: The RIT Model as a Theoretical Lens' in this special issue. 
multi-national supermarket corporations and small local retailers, or between national aquaculture industries in Norway and Thailand show. Beyond GlobalGAP's membership, other stakeholders (for example, environmental NGOs, scientific experts or government officials) are also involved in the standard-setting activities of GlobalGAP, such as through working groups and technical committees. In countries such as Kenya even national governments are involved in establishing domestic guidelines, adapting the GlobalGAP standard to the local situation to create KenyaGAP. ${ }^{26}$

\section{HYBRIDIZATION BEYOND STANDARD SETTING}

A second reason why the Governance Triangle illustrated in Figure 1.1 draws an incomplete picture of the hybridization of food governance is that it is focused on standard setting. As the various contributions in this volume show, the trend to hybridization of food governance extends beyond standard setting and involves other dynamics of food regulation. One example offered in this volume concerns the implementation of MSC certification by local fisheries and the support given to this process by state authorities. As Agni Kalfagianni and Tiffany Andrade Roche show in their analysis, states may provide powerful drivers of local MSC adoption and implementation by providing public funding schemes to achieve certification.

Clearly, regulatory governance does not concern activities of standard setting only. Hood, Scott and Baldwin conceptualize regulation as comprising three constitutive elements: standard setting, monitoring compliance, and enforcement. ${ }^{27}$ For Abbott and Snidal the regulatory process comprises at least five stages (or tasks), namely agenda-setting (placing an issue on the regulatory agenda), negotiation (bargaining, drafting and promulgating standards), implementation (implementing standards within the operations of targets of regulation such as firms), monitoring

26 Christine Carey, 'Kenya and the KenyaGAP Standard for Good Agricultural Practice. Governmental Use of Voluntary Standards'. ISEAL Case Study No 6 (2008) 11-12, accessed 24 November 2016 at http://www.isealalliance.org/sites/ default/files/E051_Kenya_KenyaGAP.pdf.

27 Christopher Hood, Henry Rothstein, Robert Baldwin (eds), The Government of Risk (Oxford University Press 2011) 26-27. See also Colin Scott, 'Regulating Everything: From Mega- to Meta-regulation' (2012) 60 Administration 61. 
compliance, and enforcement (promoting compliance and responding to non-compliance) ${ }^{28}$

In analysing private and hybrid forms of governance one important stage seems to be missing here. As regards state regulation, the step following the setting of the standards is the implementation of these standards. This can be different for private and indeed hybrid forms of governance, since they do not necessarily entail the automatic application of or the obligation to comply with the set rules. After drafting and promulgating the standards, they first need to be adopted by regulatees. Henson and Humphrey stress that the distinction between standard setting and adoption clarifies the issue of compulsion and obligation. ${ }^{29}$ Adopting a standard means deciding to accept the rules and to aim at compliance. A private entity may adopt a standard for several reasons: (i) adoption is legally mandatory, either under state law or by private contract; (ii) compliance is de facto mandatory as a result of demands by dominant actors in the market (such as retailers); or (iii) because the entity considers adoption beneficial to gain market access, to improve its reputation, to get a better price, or for some other (ethical) reason.

All in all, five principal functions seem to apply to every governance arrangement of food. ${ }^{30}$ For a food governance arrangement to be effective, rules have to be laid down and subsequently adopted and implemented, and compliance with the rules has to be monitored and enforced. All regulatory activities can be thought of as part of one of these functions: (a) agenda setting and rule-making; (b) adoption and implementation; (c) monitoring compliance; (d) enforcement; and (e) evaluation and review.

\section{(a) Agenda Setting and Rule-Making}

Agenda setting is the phase in the regulatory process in which the issue is framed as a matter of food governance, where an arena for discussion and solution of the issue is chosen, and lobbying and coalition building takes place to succeed in agreeing to the regulatory norms. Rule-making is then

28 Kenneth W. Abbott and Duncan Snidal 'The Governance Triangle: Regulatory Standards Institutions in the Shadow of the State' in Walter Mattli and Ngaire Woods (eds), The Politics of Global Regulation (Princeton University Press 2009) 63.

29 Spencer Henson and John Humphrey, 'Codex Alimentarius and Private Standards' in Bernd Van der Meulen (ed.), Private Food Law. Governing Food Chains through Contract Law, Self-Regulation, Private Standards, Audits and Certification Schemes (Wageningen Academic Publishers 2011) 149, 157.

30 Compare Havinga (n 23), 28-9 and Henson and Humphrey (n 29) 155-6. 
the activity through which the negotiations on the regulatory norms are finalized and find their way into written rules and procedures. Through rule-making, new standards are introduced and old standards revised or discarded.

\section{(b) Adoption and Implementation}

After the standard is set, the regulated business has to adopt the standard before the standard can take effect. This can take various forms. For example, a firm or group of firms can develop a standard, which they adopt voluntarily for internal purposes. The adoption of food standards may also be required by businesses (either buyers or sellers) in the supply chain. The decision of major food retailers to adopt particular food standards such as GlobalGAP or BRC and require compliance with them in their supply contracts is considered a key driver of the diffusion and influence of private foods standards, making these standards mandatory for farmers and other food producers that supply these retailers. ${ }^{31}$ The adoption by firms in the supply chain (market uptake) of standards that are developed by NGOs, such as those on kosher foods, is also crucial to their impact. ${ }^{32}$

For state regulation, the importance of the phase of adoption of the standard seems to be less obvious. From a socio-legal perspective, however, state law also has to be adopted, implemented and internalized a firm needs to identify the legislation as relevant to its own operations and decide to implement the law. A firm may be unaware of relevant laws or decide to ignore them. Implementation of the standard is all that is done by an organization to abide by the standard in its own operations.

\section{(c) Monitoring}

Monitoring involves the procedures and activities used to verify compliance with the standards. Conformity can be assessed in various ways: by internal monitoring, by self-declaration, by inspection by the buyer (second-party audit), by a third party (certification agency), by the standard

31 Fabrizio Cafaggi, 'Transnational Governance by Contract: Private Regulation and Contractual Networks in Food Safety' in Axel Marx, Miet Maertens, Johan Swinnen and Jan Wouters (eds), Private Standards and Global Governance. Economic, Legal and Political Perspectives (Edward Elgar 2012).

32 Timothy Lytton, 'Competitive Third-Party Regulation: How Private Certification Can Overcome Constraints That Frustrate Government Regulation' (2014) 15 Theoretical Inquiries in Law 539. 
setter, or by a state agency. Consumer complaints or media attention can also play a role in bringing non-compliance to the fore. ${ }^{33}$ Monitoring compliance can involve various activities such as checking documents and registrations, taking samples and lab analysis, and inspections of premises. Most private standards require some sort of (third-party) certification.

\section{(d) Enforcement}

Enforcement refers to the activities, both formal and informal, that aim to secure compliance by regulated firms with the applicable regulatory standards and the objectives these standards embody. ${ }^{34}$ Enforcement action is often taken in response to non-compliance, but in a broader understanding it may also induce compliance before an infringement is formally committed. The actor responsible for monitoring compliance might also enforce compliance. However, often other actors may become involved in case of non-compliance. Public inspectorates may forward cases of non-compliance to public prosecutors or to courts. Compliance reports from private third-party auditors will typically be sent to the certification agency or the standard owner to take further enforcement action. Sanctions can vary from warnings, instructions and advice, to fines, suspension of certification, contract termination, naming and shaming, and even consumer boycotts.

\section{(e) Evaluation and Review}

For a food governance arrangement it is crucial to be reflective, that is, the standard setter should be receptive to criticism, to the regulatory outcomes, and to new developments in food processing, food products, trading, scientific knowledge about risks and ways to prevent and detect them. Most standard owners have a procedure in place for the periodic review of their standards. The period for the review of standards is typically three to four years. Increasingly, the procedures for the revision of private standards also include consultation rounds and meetings with stakeholders.

33 See for example Lytton (n 32) 566. This only works, however, if consumers are aware of the certificate (business-to-consumer label) and are able to discover non-compliance. Frequently, certification for food (safety) standards is only allowed in business-to-business relationships and therefore consumers are not affected by any of these certificates when buying food.

34 See in greater detail: Paul Verbruggen, Enforcing Transnational Private Regulation: A Comparative Analysis of Advertising and Food Safety (Edward Elgar 2014) 16-17. 


\section{EXAMINING HYBRIDIZATION: AN ANALYTICAL FRAMEWORK}

To analyse the hybridization of food governance we propose an analytical framework that is based on the framework introduced by Eberlein et al. for the analysis of interactions in regimes of transnational business governance. ${ }^{35}$ In the previous sections, we have broken (regulatory) governance down to five different phases or functions: (a) agenda-setting and rule-making; (b) adoption and implementation; (c) monitoring; (d) enforcement; and (e) evaluation and review. Following Eberlein et al., we suggest that a comprehensive and systematic analysis of hybridization of food governance should address these five phases and functions, taking the following six dimensions into account:

\section{(a) Actors}

Which actors are involved in the hybrid governance arrangement? Each phase or function can be performed by different actors. One single actor can also perform several functions (or even all of them). Hybridization can occur when both private and public actors are involved in the same activity, for example, state actors and industry are concurrently involved in drafting the rules or in monitoring and enforcing public regulation. To give an example from this volume, the Swiss public ordinance on the use of veterinary drugs for livestock involves both state-employed and for-profit veterinarians to monitor compliance with its rules. As the contribution by Eva Thomann and Fritz Sager (Chapter 5) demonstrates, this hybrid arrangement triggers distinct accountability problems.

Hybridization may also mean that an environmental NGO succeeds in setting an issue related to food governance on the political agenda. Likewise, hybridization can concern the legislative enactment by the state of food standards, compliance with which by the regulated food businesses is overseen by both public (ministries, enforcement agencies) and private actors (industry associations, certification bodies). We have already stressed the importance of differentiating between actors in the 'actor categories' of states, firms and NGOs. In the same way, distinctions can also be drawn regarding the level of governance at which the actors

35 Burkard Eberlein, Kenneth W. Abott, Julia Black, Errol Meidinger and Stephan Wood 'Transnational Business Governance Interactions: Conceptualization and Framework for Analysis' (2014) 8 Regulation \& Governance $1,14$. 
are operating. Are they active on a global, local or intermediate (European Union, federal) level?

\section{(b) Drivers and Motives}

What are the drivers and motives of the various actors to engage in regulatory activities and, as such, to contribute to hybrid food governance? Why do the respective actors involved 'buy into' the arrangement? What are the ambitions of the actors? Insights regarding the drivers and motives for regulation offer important input for qualifying the results and determining the effectiveness that is achieved by the governance arrangement. Both Fagotto and Lytton and McAllister (Chapters 3 and 4 respectively in this volume) argue that economic motives of for-profit auditors have a negative impact on their performance. In this respect it may also be significant to examine whether the inclusion of different public and private actors was intended, or whether the mix was coincidental. Furthermore, one might ask whether the hybridization is ad hoc, experimental or whether a broader (public) policy is behind it? Is hybridization voluntary or coerced? As Kirezieva and Luning make clear in their contribution, context factors like the agro-climatic environment, the political arena, and dependence on international markets also play a key role in shaping the governance of the food safety management systems of individual firms and, by extension, the hybridization of food governance.

\section{(c) Mechanisms and Instruments}

Actors in hybrid governance arrangements interact through different means and forums. Which mechanisms and instruments are used for that purpose? Are these formal (membership, voting procedures, consultation) or informal (networks, markets and communities)? How do these mechanisms relate to organizational and governance structures, and what is their (legal) basis? A frequently applied mechanism of coordination in food standards is conditional referencing. ${ }^{36}$ Standard $\mathrm{X}$ then notes 'compliance with this standard can be demonstrated by compliance with Standard Y or Z'. As Havinga and Verbruggen demonstrate in this volume (Chapter 9), several public enforcement agencies employ this mechanism to involve

36 See more generally Eberlein et al. (n 35) 11 and Nina A. Mendelson, 'Private Control over Access to Public Law: The Perplexing Federal Regulatory Use of Private Standards' (2014) 112 Michigan Law Review 737. 
private assurance schemes in their risk-based policy for food safety controls. Statutory obligations on food businesses to have food safety management systems in place are also common in many jurisdictions (Van der Meulen (Chapter 6) and Hussein, Garcia Martinez and Fearne (Chapter 7) and Kottenstede (Chapter 10)). As the contribution by Kindji and Faure (Chapter 12) shows, however, the uptake of food safety management systems by individual firms in the member countries of the West African Economic and Monetary Union is not mandated by law. Instead, its introduction is the result of requirements imposed by European buyers sourcing from local producers.

\section{(d) Character of Interaction}

The interaction between the private and public actors involved in governance arrangements and the institutions of such arrangements can be characterized in many ways. ${ }^{37}$ Eberlein et al. distinguish four broad categories of interaction among transnational business governance schemes, and with state-based institutions. ${ }^{38}$ A first form is competition: different actors and institutions compete with each other to obtain governance capacities, including reputation, legitimacy and 'turf'. Second, actors and institutions may coordinate governance activities by devising tasks, collaboration or imitation, either conscious or inadvertent. A third form is cooptation, which emerges when actors and their institutions adopt or converge around specific standards and procedures developed by others. In the domain of food safety, norms developed by the Codex and ISO have had a significant impact on the design of hygiene regulation and procedures of food certification and accreditation (Donal Casey, Chapter 2 in this volume). Finally, the interaction may also be chaotic in that relationships have not stabilized, remain undirected and are subject to conditional swings.

Of course, while relationships between public and private actors and their institutions evolve, the interactions also evolve. Interaction may also be characterized by several forms at the same time, being, for example, cooperative in one respect and competitive in another. This means that the interaction may change form over time and can display characteristics of multiple forms. ${ }^{39}$

37 See for example Van der Heijden (n 17).

38 Eberlein et al. (n 35) 11-12.

39 Eberlein et al. (n 35) 12. 


\section{(e) Results and Effects}

Next the question arises regarding the (intermediate) results or effects of hybridization. What are the challenges and benefits, and how are these different from previous experiences with governance arrangements? How are concerns of (democratic) legitimacy and accountability addressed, if they are deemed necessary at all? Are hybrid forms of governance more effective or cost-effective than traditional state regulation? As several chapters in this volume indicate, hybrid governance arrangements may not be entirely effective due to incompatible incentives and inadequate oversight mechanisms. ${ }^{40}$

\section{(f) Change Over Time}

Finally, what changes occur in the participation of actors, the roles and functions they perform and the interactions among them? Clearly, governance arrangements develop over time. ${ }^{41}$ Standards may change ownership, ${ }^{42}$ new actors may be incorporated in the governance structure or in separate regulatory activities such as standard setting and monitoring, ${ }^{43}$ and actors may withdraw from a standard. ${ }^{44}$ Generally, we see that more actors become involved as a standard or governance arrangement matures. For transnational standards this often means that the geographical spread of the actors also increases over time. Understanding why and how these changes take effect is key to predicting the outcomes of food governance.

These six 'dimensions' of hybridization, combined with the five different phases or functions of regulatory governance, make up the analytical framework summarized by Table 1.2.

40 See Fagotto (Chapter 3), Lytton and McAllister (Chapter 4), Thomann and Sager (Chapter 5), and Hussein, Garcia Martinez and Fearne (Chapter 7) in this volume.

41 This phenomenon is widely observed in the scholarship on (regulatory) governance. See in general: Fabrizio Gilardi and Claudio Radaelli, 'Governance and Learning' in Levi-Faur (n 16) 155.

42 For example, the Safe Quality Food (SQF) standard was sold by its original developer the Government of Western Australia to the Food Marketing Institute, the trade association for US retailers.

43 For example, food manufacturers have been integrated in the governance structures of GlobalGAP (Donal Casey, Chapter 2 in this volume) and the Global Food Safety Initiative (Havinga and Verbruggen, Chapter 9 in this volume).

44 For example, after having formally established the Marine Stewardship Council (MSC) in 1997, the multinational company Unilever and the World Wide Fund for Nature withdrew from its management (see Kalfagianni and Andrade Roche, Chapter 11 in this volume). 


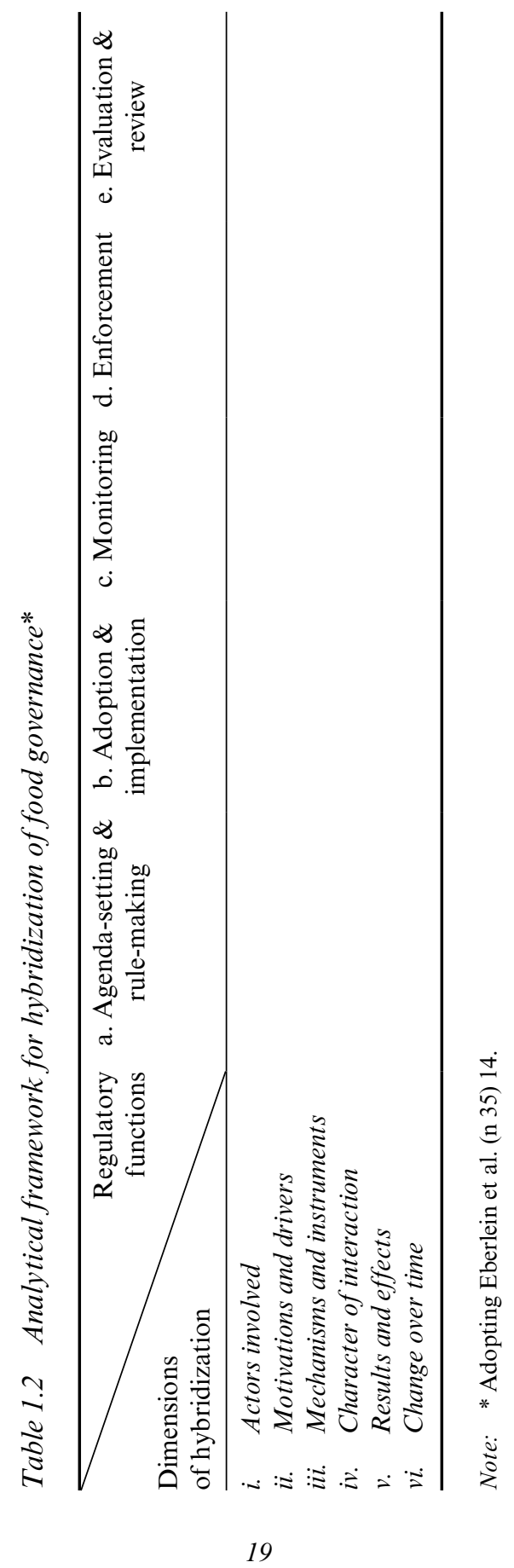

Paul Verbruggen and Tetty Havinga - 9781785361708 
To be sure, the contributions in this volume do not address all dimensions and functions identified in the table. Instead, the contributions focus on one or two particular functions of a food governance arrangement (the columns) and then address the questions triggered by the various dimensions (the rows). It should also be noted that the analytical framework proposed here does not impose a specific theoretical lens through which the contributors of the volume should look. Instead, the purpose of the framework is to provide guidance for systematically analysing the origins, forms and results of hybridization of food governance now and in the future.

\section{HYBRIDIZATION OF FOOD GOVERNANCE: TRENDS, TYPES AND RESULTS}

This volume brings together 12 contributions that examine the trends, types and results of hybridization of food governance arrangements.

\section{Part I}

The first part of the volume deals with the contested legitimacy and integrity of private food governance and asks whether and to what extent hybridization should be seen as a cause or solution to this. The rise of private food standards and its impact on (transnational) food supply chains have triggered fundamental questions about stakeholder participation, transparency, accountability, and effectiveness in standard setting and implementation. Donal Casey first examines how GLOBALGAP, which administers the most widely implemented private food certification scheme worldwide, has sought to meet legitimacy demands from various state, industry and civil society actors in relation to its scheme. As Casey shows in his analysis, the search for legitimacy by GLOBALGAP is a key driver of its interaction with state actors and civil society. More specifically, GLOBALGAP has strategically engaged with non-industry stakeholders to gather support for its standard-setting activities and has tapped into the existing system of third-party certification and accreditation in order to legitimate its own organizational structures, its practices and processes. Several strategies were used for legitimation. First, GLOBALGAP deliberately chose to build its standards on pre-existing international standards of verification and accreditation (ISO) and international standards of standard setting procedures (ISO, ISEAL, WTO). Furthermore, it engaged and communicated with state and civil society actors in order to gain their support. GLOBALGAP also recognized that 
independent verification of compliance was critical to its legitimacy. It thus relies on accredited third-party certification as the internationally accepted best practice. GLOBALGAP received endorsement from the European Co-operation for Accreditation and responded to criticism relating to inconsistent certification practices with closer cooperation with the international accreditation communities. Casey concludes that state actors, certification and accreditation organizations constitute key legitimacy communities that play a central role in providing legitimacy to non-state regulatory organizations such as GLOBALGAP.

In her contribution, Elena Fagotto addresses a specific problem that has triggered wide discussions about the integrity of private food governance, namely the conflict of interest in third-party certification. Certification plays a central role in many private and hybrid food safety arrangements. Reviewing the literature from the fields of food, accounting, labour and environmental standards, she reveals four limitations in the institutional design of third-party certification that create conflicts of interest: risks to auditor independence, poor auditor competence, inadequate audit design, and limited audit transparency. She then asks whether and to what extent the meta-rules set by the Global Food Safety Initiative (GFSI) address these four weaknesses. Although GFSI acknowledges the identified risks in its benchmarking requirements, as Fagotto acknowledges, certain gaps still remain, the most important of which is that auditors are paid by the firms they audit and that GFSI does not offer a way to avoid the resulting conflicts of interest. Other gaps include the fact that audit visits are announced in advance and that audit reports are not shared. Fagotto thus cautions that public regulators should first understand how private initiatives operate and assess their effectiveness before they devise hybrid forms of food governance. If not, such hybrid governance arrangements are likely to yield sub-optimal results.

Timothy Lytton and Lesley McAllister specifically focus on one of the institutional weaknesses of third-party certification discussed by Fagotto: the conflict between financial interests and professional obligations that arises when auditors are paid by the firms they audit. In their contribution they investigate the various oversight mechanisms that have been developed by both private and public actors in the United States to address this problem. They highlight the strengths and disadvantages of oversight by these mechanisms, which involve tort litigation in the courts, certifier accreditation and licensing, GFSI benchmarking, and government recognition of accreditation bodies. These oversight mechanisms create or increase incentives to counterbalance the incentives that result in poor food safety audits and unreliable third-party certification. The different oversight mechanisms together, as Lytton and McAllister 
contend, comprise a network of private and public actors that may fill gaps left by individual actors. Separating functions among different actors may reduce vulnerability to conflicts of interest, but networks also have disadvantages as they may result in diffuse responsibilities and increased administrative burdens and costs. Lytton and McAllister conclude that their analysis can be helpful in the design of hybridized or networked regulatory arrangements in food governance in order to reduce conflicts of interest in private auditing and improve regulatory outcomes in the United States and beyond.

In the final contribution in this section, Eva Thomann and Fritz Sager discuss the conflicting roles and accountabilities of street-level professionals in a hybrid governance regime. They use empirical data on the enforcement of the Swiss regulations on the dispensing and use of veterinary drugs for livestock by public and private veterinarians. Thomann and Sager compare the performance of public and private veterinarians and conclude that implementation failures exist both with public and private veterinarians, but are more severe among the latter. They use the concept of accountability regimes to explain how veterinarians do their job. The complex relationships between actors in a hybrid regime create conflicting roles. Private veterinarians are simultaneously implementing agents, policy addressees, professionals, and market actors. Private veterinarians provide for-profit services to farmers and are at the same time supposed to enforce public regulations on the same farmers. The resulting conflicts of interest are very similar to the conflicts of interest faced by auditors in third-party certification schemes, as Lytton and McAllister have shown. The public veterinarians are supposed to monitor their private colleagues. The relationship between public and private veterinarians is complex because private veterinarians are simultaneously professional peers, enforcement agents and target group, and this restricts the possibilities the public veterinarians have to enforce the regulations on their private colleagues. The authors contend that two aspects of hybrid governance regimes are problematic: private actors who are assigned different tasks (addressee and enforcement agent) and the irreconcilable rationalities of the state and the market (each controlling their own customers). Thomann and Sager conclude that hybridity can have concrete, negative effects that should be taken into account to ensure the compliance of regulatees with food safety regulations.

\section{Part II}

The second part of the volume focuses on the hybridization of food governance in the European Union. Legislation and public policy have both 
provided a powerful impetus for this development in Europe. Bernd van der Meulen therefore first examines how the European legislature has contributed to the rise of hybrid food governance. By focusing on EU food hygiene law, he contends that public and private regulation live in close symbiosis to ensure the policy objective of food safety. He distinguishes between three forms of private regulation in which this symbiosis exists: firm-level HACCP systems made mandatory through statutory rules, guides for good hygienic practices adopted by industry associations, and so-called 'external private regulation' set by powerful firms in the food supply chain (that is, large corporate retailers and producers) with a view to ensuring that food safety is effectively ensured in any of the preceding links in the chain. As Van der Meulen shows, both EU legislation and the case law of the European Court of Justice contribute to the trend towards the hybridization of food governance in the European Union. Inevitably, this will entail a more complex regulatory framework for food safety.

While Van der Meulen's contribution is mainly concerned with the interplay between public and private actors in rule-making activities, the other two contributions in this second part provide empirical insights into the adoption, implementation and enforcement of hybrid regulatory arrangements at individual firm level. First, Mohamud Hussein, Marian Garcia Martinez and Andrew Fearne analyse the operation of so-called 'management-based regulation' in the fresh poultry meat sector in the United Kingdom. This hybrid form of food regulation requires individual companies to engage in their own planning, rule-making and enforcement activities to deliver safe food products based on HACCP principles. While management-based regulation is expected to ensure higher levels of food safety at lower cost to the public regulators, it has not met these expectations in the UK poultry sector. Firms in this sector may not only lack the necessary knowledge and financial resources to deliver safe food, but may also have conflicting incentives to comply with the rules. Hussein, Garcia Martinez and Fearne thus caution that without a well-crafted regulatory incentive mechanism capable of committing firms to ensuring a safe meat supply, the regulatory outcomes of hybrid food governance will be sub-optimal.

Subsequently, Klementina Kirezieva and Pieternel Luning discuss the influence of context factors on food safety management systems in the fresh produce sector (leafy greens), the performance and uptake of private standards by individual firms in that sector, in the European Union and beyond. Building on concepts derived from systems theory, they develop an assessment tool to measure the performance of food safety management systems for leafy greens. Climatic conditions for agricultural production, the degree of export to international markets, and government 
responsiveness to private standards are found to be important factors that contribute to demands for private standards and certification in different countries. Furthermore, where local institutional environments fail to support companies in adopting, implementing and evaluating food safety management systems, as in developing countries, there is a high demand for private standards to help to deliver food safety from individual firms that supply to international markets. Kirezieva and Luning stress the need for further investigation of how individual companies in the fresh produce sector can best design and operate their own food safety management systems while being responsive to the institutional environment in which they operate.

\section{Part III}

The third and final part of the volume concerns hybridization in global food governance. The contributions in this part are clustered around the question of how global private food standards interact with public actors and regulation at the domestic level.

Tetty Havinga and Paul Verbruggen first examine the interaction between the leading global private governance organization, the Global Food Safety Initiative (GFSI), and government actors in Canada, China, the Netherlands and the United States. Havinga and Verbruggen set out to assess why and how such public-private interaction unfolds, and with what results. For GFSI the principal reason for engagement with public authorities is to gain broad acceptance of its benchmarking process, recognized food safety schemes and the system of third-party certification. While such engagement might also strengthen their legitimacy claims, the ultimate goal of these activities is that national and international government actors recognize or adopt GFSI third party certification as accepted tools to assist in the prioritization of public food safety inspections. The principal strategy pursued by GFSI has been providing information about its organization, activities and achievements to public officials and responding to public concerns about GFSI. Havinga and Verbruggen contend that government actors have two main arguments to engage with GFSI and related private governance arrangements in the food industry. First, they want to communicate with key actors in the private sector because they are concerned about the spread of private food standards and want to stress the importance and prevalence of public laws and enforcement. Second, they want to explore the potential of private food safety schemes to contribute to public policy goals. The recently adopted food laws in Canada and the United States, for example, have benefited from the experience of GFSI and private food safety schemes, and incorporate (to different 
degrees) these schemes in the new legal framework for food regulation. Also in China and the Netherlands public food authorities entertain relationships with GFSI and its recognized third party certification schemes, albeit for very different reasons and motivations. Nevertheless, the result is an increasingly hybrid system of food governance.

The contribution by Kai Kottenstede focuses specifically on the reception of transnational private food safety standards in China. As his empirical analysis shows, the interaction between transnational private standards and the Chinese regime of food safety regulation creates a specific type of hybridization, not seen elsewhere. The Chinese government is currently actively engaging with private organizations representing the western food industry to ratchet up the implementation and enforcement of food safety standards locally. It is well known that China has experienced multiple high-impact food safety crises in the last two decades. In response, China has adopted new legislation that meets internationally accepted standards for food safety regulation. Nevertheless, important practical obstacles remain to the effective implementation and enforcement of these laws. One way the Chinese government has sought to address these obstacles has been to adopt the voluntary standards of ChinaGAP and China HACCP, and submit these standards to the benchmarking procedures provided by GLOBALGAP and GFSI to assess their equivalence to internationally accepted food safety standards. This submission of public regulation to private regulatory structures is clearly strategic. As Kottenstede shows, the Chinese government thus aims to harness the content of its own voluntary standards and increase the status and credibility of these standards among western food manufacturers sourcing products from China. At the same time, however, it seeks to limit the influence of major transnational private schemes in China, such as BRC and GLOBALGAP, by presenting to local producers a national standard that is considered technically equivalent to these international standards. While hybridization is thus clearly happening, its form and degree is closely orchestrated by the Chinese government.

Agni Kalfagianni and Tiffany Andrade Roche also engage in an empirical analysis of the reception at the domestic level of transnational private food standards. Their analysis, however, focuses on the world's most widely implemented private certification scheme for sustainable wildcaptured fish, namely the Marine Stewardship Council (MSC). Building on extensive documentary analysis and interviews with experts, they highlight the variation of domestic responses to the MSC scheme in Alaska, Australia and Ecuador. To measure that variation they use the indicators of public funds to support local MSC uptake, the co-option of the MSC scheme in domestic public regulation, and the development of rival standards supported by the state. While the reception of MSC in Australia and 
Ecuador has been quite smooth, MSC has been widely criticized in Alaska for inconsistencies in certification and the level of protection offered by the scheme itself. These variations, Kalfagianni and Andrade Roche argue, can be explained by the perceived credibility of MSC by domestic actors, MSC's complementarity to public regulation, and the significance of MSC certification for local fisheries to access international markets. In Alaska, MSC scores rather poorly on all of these explanatory factors, whereas the opposite is true in Australia and Ecuador.

Overall, the studies by Kalfagianni and Andrade Roche and Kottenstede draw attention to the importance of domestic and local levels of governance for the legitimacy and effectiveness of transnational private standards in food and other domains. Moreover, the study by Kévine Kindji and Michael Faure also stresses the role of local context factors to the uptake and effectiveness of transnational private food standards, and more generally, food safety regulation. In this contribution, Kindji and Faure explore the role of transnational private standards in harnessing the capacity of the public and private sector in the West African Economic and Monetary Union (l'Union économique et monétaire ouest-africaine UEMOA). The seven Member States of this international organization for cooperation between countries in West Africa (Benin, Burkina Faso, Ivory Coast, Mali, Niger, Senegal and Togo) face great difficulties in meeting modern demands for food safety in international markets. While regulatory reforms have been initiated, partly in dialogue with food manufacturers and producers, states frequently lack the financial means, expertise and organizational capacities (such as competent laboratories) to implement the new laws effectively. Transnational private standards may fill this governance gap, especially for producers in export-oriented supply chains. However, these producers form the top of the market. Small-and-medium sized enterprises lack the financial means to meet the requirements under transnational private standards and have sufficient difficulties meeting the newly implemented public standards.

\section{CONCLUSION}

The contributions in this book highlight the diversity in the hybridization of today's food governance. The chapters document that across a wide variety of contexts public and private actors are engaging with each other to enhance their individual or combined regulatory capacity. The collection also shows that collaboration - in whatever shape - between public and private actors is not a given, and even if such collaboration is established, the actors meet great difficulties in maintaining the carefully 
constructed balance of that collaboration because of changing and conflicting interests, rationalities, laws and organizations. It is evident that both public and private actors will only to some extent submit their autonomy to collaborative efforts. Clearly, contemporary food governance, and in particular the development of hybrid governance arrangements, is in a state of flux. It is to be expected that the trend towards hybridization discussed in this book will continue to progress. In analysing this development and the challenges it brings about, we hope the reader of this volume finds guidance in the contributions that it holds and the analytical framework we propose. 
Paul Verbruggen and Tetty Havinga - 9781785361708 Downloaded from PubFactory at 04/26/2023 01:29:10PM via free access 